\title{
PENGARUH MANAJEMEN RISIKO TERHADAP KINERJA KEUANGAN (STUDY PADA PERBANKAN SYARIAH YANG TERDAFTAR DI BEI)
}

\author{
Mardiana \\ Fakultas Ekonomi Universitas Islam Negeri Maulana Malik Ibrahim \\ Malang \\ Email: mardiana@uin-malang.ac.id
}

\begin{abstract}
The objectives of this research to analize the influence risk management is as proxy of Capital Adequacy Ratio (CAR), Operation Efficiency (BOPO), Non Performing Loan (NPL), to Financial Performance is as proxy of Return on Asset (ROA) Banking Firms wich listed on BEI in 2011 until 2016 periods. This research using time series data from Bank Indonesia's published financial reports Banking Firms wich listed on BEI in 2002 until 2007 periods. After passed the purposive sampling phase, the number of valid sample is 5 Banking Firms wich listed on BEJ. The result of this research shows that CAR and NPL variables has a negative and unsignificant influence to ROA. BOPO variable also has a significant influence to $R O A$, the distinction between BOPO than another variables is the sign of variable coefficient, it has negative coefficient. It's mean that the bank managements should be concern on the BOPO variable to improve profitability on their Financial Performance. Disintermediary functions of bank that occurs in the research periods is the reason for unsignificant CAR and NPL variable to ROA variable wich is as a proxy of Financial Performance Banking Firms.
\end{abstract}

Keywords: Operation Efficiency, Credit Risk, Liquidity, Financial Performance.

\section{PENDAHULUAN}

Manajemen risiko organisasi adalah suatu sistem pengelolaan risiko yang dihadapi oleh organisasi secara komprehensif untuk tujuan meningkatkan nilai perusahaan (Hanafi, 2006). Manajemen risiko perbankan diartikan dalam Peraturan Bank Indonesia no. 11/25/PBI/2009 tentang Perubahan atas Peraturan Bank Indonesia no. 5/8/PBI/2003 tentang Penerapan Manajemen Risiko bagi Bank Umum sebagai serangkaian metodologi dan prosedur yang digunakan untuk mengidentifikasi, mengukur, memantau, dan mengelola risiko yang timbul dari seluruh kegiatan usaha bank.

Manajemen risiko perbankan diterapkan pada seluruh kegiatan perbankan, salah satunya adalah kegiatan pemberian kredit. 
Pengendalian risiko kredit dilakukan melalui serangkaian proses manajemen risiko perbankan. Proses manajemen risiko perbankan terdiri dari idenfikasi risiko, pengukuran dan evaluasi risiko, serta pengelolaan risiko (Sulhan, 2008).

Berdasar Outlook Perbankan Syariah tahun 2014, Bank Umum Syariah (BUS) sejumlah 11, Unit Usaha Syariah (UUS) sejumlah 23 dan BPRS sejumlah 160, (www.bi.go.id). Hingga April 2016 jumlah bank syariah di Indonesia berjumlah 199 bank syariah yang terdiri dari 12 Bank Umum Syariah (BUS), 22 Unit Usaha Syariah (UUS), dan 165 Bank Pembiayaan Rakyat Syariah (BPRS (www.ojk.go.id). Hal ini menunjukkan bahwa perkembangan sektor syariah di Indonesia mempunyai sektor keuangan syariah yang cukup mampu dalam mengelola keuangan/dana masyarakat. Sementara itu, kemampuan penyaluran pembiayaan tumbuh sekitar $41 \%$ per tahun. Pertumbuhan rata-rata pembiayaan UUS adalah 45\% dan BUS adalah 43\% (Rustam, 2013).

Manajemen risiko ini dijadikan sebagai landasan bank/lembaga keuangan dalam mengambil, menentukan dan melaksanakan tindakan atau langkah yang tepat. Manajemen risiko seringkali dipersepsikan sebagai penghambat kemajuan, memperlama proses internal perusahaan dan membebani keuangan perusahaan, serta hal negatif lainnya. Namun setelah menghadapi dan mengalami krisis moneter serta krisis keuangan global, akhirnya para pelaku ekonomi mengakui bahwa penerapan manajemen risiko pada bank atau lembaga keuangan telah menjadi suatu kebutuhan, termasuk dalam meraih peluang bisnis. Implementasi sistem manajemen risiko yang baik dapat mengendalikan risiko dan meningkatkan kinerja keuangan bank/lembaga keuangan.

Salah satu keberhasilan mengukur kinerja keuangan suatu perusahaan khususnya bank yaitu dengan mengukur tingkat pengembalian atas asset atau return on asset (ROA) yang tentunya bisa menjadi tolak ukur dalam pengambilan keputusan perusahaan. Return on asset (ROA) dapat digunakan untuk menilai kondisi rentabilitas perbankan di Indonesia. Semakin tinggi ROA, berarti bank semakin efektif dalam penggunaan aktiva untuk menghasilkan keuntungan. Peningkatan ROA dapat direalisasikan jika bank dapat bekerja dengan efisien (Hamidah, 2013).

Adapun tujuan dari penelitian ini adalah mengetahui pengaruh manajemen risiko yang diproksikan dengan Capital Adequacy Ratio 
(CAR), Biaya Operasional terhadap Pendapatan Operasional (BOPO) dan Non performing loan (NPL), secara simultan dan parsial terhadap kinerja keuangan.

\section{Manajemen Risiko}

Manajemen risiko adalah serangkaian prosedur dan metodelogi yang digunakan untuk mengidentifikasi, mengukur, memantau dan mengendalikan risiko yang timbul dari kegiatan bank

Pada Peraturan Bank Indonesia No.11/25/PBI/2009, Bank Indonesia mengidentifikasi 4 aspek pokok yang minimal ada dalam manajemen risiko, yaitu diantaranya, pertama adalah pengawasan aktif dewan komisaris dan direksi. Kedua adalah kebijakan, prosedur, dan penetapan limit. Ketiga adalah proses identifikasi, pengukuran, pemantauan, sistem informasi manajemen risiko kredit. Keempat adalah Pengendalian Risiko Kredit. Salah satu risiko yang sering dihadapi bank adalah risiko adanya pinjaman bermasalah yaitu ketika pihak debitur tidak mampu memenuhi kewajibannya untuk membayar angsuran (cicilan) pokok kredit beserta bunga yang telah disepakati kedua belah pihak dalam perjanjian kredit. Hal tersebut disebut dengan risiko kredit (Dendawijaya, 2005).

Risiko kredit timbul karena kinerja satu atau lebih debitur yang buruk, kinerja debitur yang buruk ini dapat berupa ketidakmampuan debitur untuk memenuhi sebagian atau seluruh isi perjanjian kredit yang telah disepakati sebelumnya (Setiawan, 2007). Aktivitas kredit sendiri merupakan salah satu kegiatan utama sebuah bank karena bila bank tidak memberikan kredit kepada debitur berarti tidak ada uang yang berputar dan tidak ada bunga yang dapat ditarik dari para peminjam. Padahal bunga kredit tersebut merupakan pendapatan utama dari sebuah bank. Dari penjelasan tersebut, dapat disimpulkan bahwa pemberian kredit merupakan suatu aktivitas yang tidak dapat dihindari dari sebuah bank dan adanya aktivitas kredit pasti juga akan diikuti kemungkinan timbulnya risiko kredit.

\section{Tipe risiko}

Menurut hanafi (2006), Risiko dapat dikelompokkan ke dalam dua tipe risiko, yaitu risiko murni dan risiko spekulatif. 
Risiko murni adalah risiko dimana kemungkinan kerugian ada, tetapi kemungkinan keuntungan tidak ada. Tipe risiko murni , menurut hanafi (2006), adalah:

1. Risiko asset fisik.

Risiko yang terjadi karean kejadian tertentu berakibat buruk pada asset fisik organisasi.

2. Risiko Karyawan.

Risiko karena karyawan organisasi mengalami peristiwa yang merugikan.

3. Risiko Legal

Risiko kontrak tidak sesuai yang diharapkan, dokumentasi yang tidak benar.

Risiko Spekulatif adalah risiko dimana kita mengharapkan terjadinya kerugian dan juga keuntungan. Tipe risiko spekulatif , menurut hanafi (2006), adalah:

1. Risiko pasar.

Risiko yang terjadi dari pergerakan harga atau volatilitas harga pasar.

2. Risiko kredit.

Risiko karena counter party gagal memenuhi kewajibannya kepada perusahaan.

3. Risiko likuiditas.

Risiko tidak bisa memenuhi kebutuhan kas, risiko tidak bisa menjual dengan cepat karena ketidaklikuid dan atau gangguan pasar.

4. Risiko operasional .

Risiko kegiatan operasional tidak berjalan lancar dan mengakibatkan kerugian: kegagalan sistem, human error, pengendalian dan prosedur yang kurang.

\section{Proses manajemen risiko}

Proses manajemen risiko memberikan gambaran kepada kita bahwa untuk mengelola risiko ada beberapa tahapan yakni:

1. Perencanaan Manajemen Risiko.

Perencanaan meliputi langkah memutuskan bagaimana mendekati dan merencanakan kegiatan manajemen risiko untuk sebuah proyek. Dengan mempertimbangkan lingkup proyek, rencana manajemen 
proyek, faktor lingkungan perusahaan, maka tim proyek dapat mendiskusikan dan menganalisis aktivitas manajemen risiko untuk proyek-proyek tertentu.

2. Identifikasi Risiko

Sebagai suatu rangkaian proses, identifikasi risiko dimulai dengan memahami apa sebenarnya yang disebut sebagai risiko. Berikutnya adalah pendefinisian risiko yang mungkin mempengaruhi tingkat keberhasilan proyek dan mendokumentasikan karakteristik dari tiap-tiap risiko dengan melakukan Hasil utama dari langkah ini adalah risk register.

3. Analisis Risiko Kualitatif

Analisis kualitatif manajemen risiko adalah proses menilai dampak dan kemungkinan risko yang sudah diidentifikasi. Proses ini dilakukan dengan menyusun risiko berdasarkan dampaknya terhadap tujuan proyek.

4. Analisis Risiko Kuantitatif

Analisis risiko secara kuantitatif merupakan metode untuk mengidentifikasi risiko kemungkinan kegagalan sistem dan memprediksi besarnya kerugian. Analisis ini dilakukan dengan mengaplikasikan formula matematis yang dikaitkan dengan nilai finansial. Secara matematis penghitungan risiko dilajkukan dengan mengalikan tingkat kemungkinan kejadian dengan dampak yang ditimbulkan.

5. Penanganan Risiko

Penangan risiko diartikan sebagai proses yang dilakukan untuk meminimalisasi tingkat risiko yang dihadapi sampai pada batas yang dapat diterima. Sacara kuantitatif, upaya meminimalisasi risiko dilakukan dengan menerapkan langkah-langkah yang diarahkan pada turunnya angka hasil ukur yang diperoleh dari analisis risiko.

\section{Kinerja Keuangan}

Kinerja keuangan dapat dilihat dari segi profitabilitas perusahaan tersebut dimana profitabilitas menunjukkan kemampuan suatu perusahaan dalam menghasilkan laba.Pengukuran kinerja secara garis besar dikelompokkan menjadi dua, yaitu pengukuran non finansial dan financial (Sari, 2010). Kinerja non finansial adalah pengukuran kinerja dengan menggunakan informasi informasi non finansial yang lebih dititikberatkan dari segi kualitas pelayanan kepada pelanggan. 
Sedangkan pengukuran kinerja secara finansial adalah penggunaan informasi-informasi keuangan dalam mengukur suatu kinerja perusahaan. Informasi keuangan yang lazim digunakan adalah laporan laba rugi dan neraca. Kinerja perusahaan bisa diukur dengan rasio-rasio keuangan lain, seperti market share growth, return on investment (ROI), return on asset (ROA), ROI growth, return on sales (ROS), ROS growth assets, price eraning ratio, Tobin's $Q$ dan rasio-rasio keuangan lainnya.

\section{return on asset}

Return on Asset merupakan rasio antara laba sebelum pajak terhadap total asset. Semakin besar Return on Asset menunjukkan kinerja keuangan yang semakin baik, karena tingkat kembalian (return) semakin besar. Apabila Return on Asset meningkat, berarti profitabilitas perusahaan meningkat, sehingga dampak akhirnya adalah peningkatan profitabilitas yang dinikmati oleh pemegang saham (Husnan, 1998).

Dalam penelitian ini Return on Asset (ROA) dipilih sebagai indikator pengukur kinerja keuangan perbankan adalah karena Return on Asset digunakan untuk mengukur efektifitas perusahaan didalam menghasilkan keuntungan dengan memanfaatkan aktiva yang dimilikinya.

Menurut Horne (1995), analisis trend dari rasio keuangan mempunyai dua tipe perbandingan salah satunya adalah rasio keuangan dituangkan dalam spreadsheet untuk periode beberapa tahun, sehingga dapat mempelajari komposisi dan faktor-faktor yang menyebabkan perusahaan tersebut berkembang atau bahkan menurun. Informasi tentang kinerja keuangan pada lembaga keuangan (dalam hal ini perbankan) dalam periode tertentu, dapat diketahui dengan menganalisis rasio-rasio keuangan.

\section{Faktor-faktor yang mempengaruhi kinerja keuangan}

Kinerja keuangan sebagai sebuah variabel yang selama ini sering dijadikan bahan penelitian, dipengaruhi oleh beberapa faktor, yaitu: good corporate governance (GCG), struktur kepemilikan, manajemen risiko kredit.

1. Good Corporate Governance

Pengertian good corporate governance menurut World Bank dalam Wahyuni (2012) adalah kumpulan hukum yang wajib dipenuhi untuk mendorong kinerja secara efisien sehingga menghasilkan nilai 
ekonomi jangka panjang bagi pemegang saham maupun masyarakat sekitar. Tata kelola tersebut diwujudkan dalam satu sistem pengendalian perusahaan guna menjaga kinerja perusahaan tetap optimal. Pengimpelementasian good corporate governance (GCG) pada suatu perusahaan dapat dilakukan dengan beberapa mekanisme pemantauan tata kelola perusahaan.

2. Ukuran Perusahaan

Dhanis (2012) menyebutkan bahwa ukuran perusahaan merupakan rata-rata total penjualan bersih untuk tahun yang bersangkutan sampai beberapa tahun. Ketika ukuran perusahaan ditentukan oleh jumlah penjualan suatu perusahaan, maka semakin besar jumlah penjualan yang dilakukan oleh perusahaan semakin besar pula profit yang akan diperoleh sehingga kinerja keuangan perusahaan pun akan meningkat.

3. Efisisensi Perbankan

Tingkat efisiensi bank adalah pengukuran seberapa besar kemampuan bank dalam melakukan kegiatan operasionalnya (Ibadil, 2013). Tingkat efisiensi perbankan biasanya diproksikan dengan rasio BOPO yang merupakan rasio antara biaya operasi dibagi pendapatan operasi. Besar kecilnya rasio ini menunjukkan kemampuan suatu perusahaan dalam mengelola usahanya. Peningkatan rasio ini menggambarkan tingkat efisiensi yang rendah. Tingkat efisiensi yang rendah akan berimbas pada penurunan kinerja keuangan perusahaan.

\section{Pengaruh manajemen risiko yang terdiri CAR, BOPO dan NPL terhadap kinerja Secara Simultan maupun Parsial}

Purwoko dan Sudiyatno (2013) mengungkapkan bahwa risiko adalah penyimpangan hasil aktual dari hasil yang diharapkan atau probabilitas suatu hasil yang berbeda dari yang diharapkan. Risiko dapat dikategorikan menjadi empat kategori yaitu risiko pasar, risiko kredit, risiko operasional, dan risiko reputasi. Barajas (1999) mengatakan bahwa kualitas pinjaman yang tidak berjalan dengan lancar berpengaruh positif terhadap spread suku bunga. Pinjaman yang tidak berjalan lancar akan mengakibatkan manajer bank menambah biaya operasional untuk menghadapi risiko dari adanya pinjaman tidak lancar tersebut. Suatu manajemen risiko dapat dikatakan berhasil bilamana berhasil meminimalisir risiko-risiko tadi ke tingkat yang aman. Dari beberapa 
argumentasi diatas, secara umum dapat dirumuskan hipotesis sebagai berikut :

H1.1 Diduga manajemen risiko yang diproksikan dengan modal (CAR), efisiensi operasi (BOPO), resiko kredit (NPL), berpengaruh secara simultan terhadap kinerja perbankan syariah

Menurut Muljono (1999), Capital Adequacy Ratio adalah suatu rasio yang menunjukkan sampai sejauh mana kemampuan permodalan suatu bank untuk mampu menyerap risiko kegagalan kredit yang mungkin terjadi sehingga semakin tinggi angka rasio ini, maka menunjukkan bank tersebut semakin sehat, begitu juga dengan sebaliknya. Angka rasio CAR yang ditetapkan oleh Bank Indonesia adalah minimal 8\%, jika rasio CAR sebuah bank berada dibawah 8\% berarti bank tersebut tidak mampu menyerap kerugian yang mungkin timbul dari kegiatan usaha bank, kemudian jika rasio CAR diatas 8\% menunjukkan bahwa bank tersebut semakin solvable. Dengan semakin meningkatnya tingkat solvabilitas bank, maka secara tidak langsung akan berpengaruh pada meningkatnya kinerja bank, karena kerugian-kerugian yang ditanggung bank dapat diserap oleh modal yang dimiliki bank tersebut.

Penelitian yang dilakukan Achmad et, al, (2003) menunjukkan bahwa Capital Adequacy Ratio (CAR) sangat berpengaruh terhadap kebangkrutan bank. Sementara penelitian yang dilakukan oleh Mawardi (2005), menyimpulkan bahwa, Capital Adequacy Ratio (CAR) tidak berpengaruh terhadap Return on Asset (ROA) yang merupakan proksi dari kinerja keuangan bank karena secara statistik nilai Capital Adequacy Ratio (CAR) tidak signifikan. Dari beberapa argumentasi diatas, secara umum dapat dirumuskan hipotesis sebagai berikut :

H1.2 Diduga manajemen risiko yang diproksikan dengan modal (CAR), berpengaruh secara positif dan signifikan terhadap kinerja perbankan syariah

Menurut Bank Indonesia, efisiensi operasi diukur dengan membandingkan total biaya operasi dengan total pendapatan operasi atau yang sering disebut BOPO. Rasio BOPO ini bertujuan untuk mengukur kemampuan pendapatan operasional dalam menutup biaya 
operasional. Rasio yang semakin meningkat mencerminkan kurangnya kemampuan bank dalam menekan biaya operasional dan meningkatkan pendapatan operasionalnya yang dapat menimbulkan kerugian karena bank kurang efisien dalam mengelola usahanya (SE. Intern BI, 2004). Bank Indonesia menetapkan angka terbaik untuk rasio BOPO adalah dibawah 90\%, karena jika rasio BOPO melebihi 90\% hingga mendekati angka $100 \%$ maka bank tersebut dapat dikategorikan tidak efisien dalam menjalankan operasinya.

Dari beberapa argumentasi diatas, secara umum dapat dirumuskan hipotesis sebagai berikut :

H1.3 Diduga manajemen risiko yang diproksikan dengan efisiensi operasi (BOPO), berpengaruh secara negatif dan signifikan terhadap kinerja perbankan syariah

Peraturan Bank Indonesia Nomor 13/1/PBI/2011 tentang Penilaian Tingkat Kesehatan Bank Umum menyatakan bahwa semakin tinggi nilai NPL (di atas 5\%) maka bank tersebut semakin tidak sehat. Secara teori, ketika nilai NPL semakin tinggi maka bank tersebut pun semakin tidak sehat karena tingginya risiko kredit yang harus ditanggung oleh bank. Kondisi bank yang semakin tidak sehat tentu saja akan sangat mempengaruhi keputusan investasi para stakeholder karena profitabilitas bank yang pasti akan semakin menurun.

Ariyanti (2010) menyatakan bahwa semakin kecil rasio non performing loan (NPL) semakin kecil pula risiko yang ditanggung pihak bank. Demikian sebaliknya semakin besar non performing loan (NPL) maka semakin besar pula risiko kegagalan kredit yang disalurkan, yang berpotensi menurunkan pendapatan

bunga serta menurunkan laba.

Dalam penelitian ini, manajemen risiko dikatakan berhasil atau baik jika mampu menekan rasio non performing loan (NPL). Dari berbagai penjelasan di atas, maka dirumuskan hipotesis sebagai berikut. H1.4 = Diduga manajemen risiko yang diproksikan dengan resiko kredit (NPL), berpengaruh secara negatif dan signifikan terhadap kinerja perbankan syariah 


\section{METODE}

Merujuk pada rumusan masalah, maka jenis penelitian ini adalah kuantitatif. Penelitian mengenai pengaruh manajemen risiko yang di proxikan dengan dengan modal (CAR), efisiensi operasi (BOPO), resiko kredit (NPL), terhadap kinerja perbankan syariah yang terdaftar dalam BEI ini merupakan penelitian berbasis pengujian hipotesis. Penelitian ini menggunakan data dari laporan keuangan perbankan yang terdaftar dalam BEI periode 2011-2016. Pengujian pada penelitian ini dilakukan berdasarkan data sekunder, dengan menggunakan analisis regresi.

\section{Definisi Operasional dan Metode Pengukuran Varibel}

Variabel yang akan digunakan dalam penelitian ini adalah variabel independen yaitu manajemen risiko yang terdiri dari modal (CAR), efisiensi operasi (BOPO), resiko kredit (NPL). Variabel dependen yaitu, kinerja keuangan (ROA).

\section{Pengukuran Variabel}

a. Variabel Dependen

Variabel dependen (variabel terikat) adalah variabel yang dipengaruhi atau yang menjadi akibat karena ada variabel independen (Sugiyono, 2010). Variabel dependen dalam penelitian ini adalah kinerja keuangan diproksikan dengan rasio Return On Asset (ROA). Rasio ini digunakan untuk mengukur kemampuan manajemen bank dalam memperoleh keuntungan (laba sebelum pajak) yang dihasilkan dari ratarata total aset bank yang bersangkutan sehingga semakin besar ROA, semakin besar pula tingkat keuntungan yang dicapai bank.

Surat Edaran Bank Indonesia, No.03/30/DNDP tanggal 14 Desember 2001, Return On Asset (ROA) merupakan rasio perbandingan antara laba sebelum pajak dengan rata-rata total aset. Sehingga rasio return on asset (ROA) dirumuskan sebagai berikut:

$$
R O A=\frac{\text { laba sebelum pajak }}{\text { rata }- \text { rata total aset }} \times 100 \%
$$

\section{b. Variabel Independen \\ Variabel independen (variabel bebas) adalah variabel yang menjadi sebab timbulnya atau berubahnya variabel dependen (variabel terikat) (Sugiyono, 2010). Adapun variabel independen dalam penelitian}


ini adalah manajemen risiko / Risiko kredit diproksi dengan menggunakan

1. Penilaian atas aspek permodalan adalah Capital Adequacy Ratio (CAR).

CAR adalah rasio kinerja bank untuk mengukur kecukupan modal.

$$
C A R=\frac{\text { modal }}{\text { aktiva tertimbang memurut risiko }}
$$

2. Rasio non performing loan.

Rasio Non Performing Loan (NPL) merupakan perbandingan kredit bermasalah terhadap kredit yang disalurkan. Jadi rasio ini menggambarkan tentang risiko adanya kredit bermasalah yang dialami bank. Menurut Surat Edaran Bank Indonesia No.03/30/DNDP tanggal 14 Desember 2001, non performing loan (NPL) dapat diukur sebagai berikut.

$$
N P L=\frac{\text { KREDIT BERMASALAH }}{\text { KREDIT YANG DISALURKAN }} X 100 \%
$$

3. Biaya Operasional terhadap Pendapatan Operasional (BOPO)

Rasio ini sering disebut rasio efisiensi karena rasio ini digunakan untuk mengukur kemampuan manajemen bank dalam mengendalikan biaya operasional terhadap pendapatan operasional.

$$
\mathrm{BOPO}=\frac{\text { biaya operasional }}{\text { pendapatan operasional }} \times 100 \%
$$

\section{HASIL DAN PEMBAHASAN}

\section{Hasil Uji Regresi}

Hasil perhitungan regresi linear berganda digunakan untuk memprediksi besarnya hubungan antara variable dependen yaitu Kinerja Keuangan/ROA (Y) dengan variable independen yaitu Capital Adequacy Ratio/CAR (X1), Biaya Operasional terhadap Pendapatan Operasional/BOPO (X2), Non performing loan/NPL (X3). Hasil estimasi regrasi linear berganda perhitungan tersebut di tunjukkan dalam Tabel 1 dibawah ini: 
Tabel.1

Hasil estimasi regrasi linear berganda

\begin{tabular}{|l|l|l|l|l|}
\hline $\begin{array}{l}\text { Variabel } \\
\text { bebas }\end{array}$ & $\begin{array}{l}\text { Koefisien } \\
\text { Regresi }\end{array}$ & T Hitung & Sig.t & Keterangan \\
\hline $\begin{array}{l}\text { Konstanta } \\
\text { CAR (X1) }\end{array}$ & -0.022 & -1.471 & 0.153 & Tidak \\
BOPO (X2) & -0.081 & -5.406 & 0.000 & Signifikan \\
NPL (X3) & -0.062 & -0.459 & 0.650 & Signifikan \\
& & & Tidak \\
& & & Signifikan \\
\hline R R-Square & $=0.796$ & \\
Adj. & $=0.549$ & & \\
Square & $=12.782$ & & \\
F Hitung & $=0.000$ \\
Sig. F &
\end{tabular}

\section{Uji Signifikansi Simultan (Uji Statistik F)}

Uji $\mathrm{F}$ digunakan untuk menguji signifikansi pengaruh antara manajemen risiko (CAR, BOPO, dan NPL) terhadap kinerja keuangan secara simultan. Hasil pengolahan data SPSS pengujian hipotesis ditunjukkan pada tabel berikut ini:

Berdasarkan hasil uji simultan di atas (tabel 1) menunjukkan bahwa nilai signifikansinya lebih kecil dari 0,05 yaitu sebesar 0,000. Artinya manajemen risiko yang diproksikan dengan CAR, BOPO, dan NPL secara simultan berpengaruh terhadap kinerja keuangan, maka $\mathrm{H}_{1}$ dalam penelitian ini diterima.

\section{Uji Signifikansi Parameter Individual (Uji Statistik t)}

Pengujian ini bertujuan untuk menguji pengaruh variabel bebas secara parsial atau sendiri-sendiri terhadap variabel terikat. Berdasarkan hasil uji parsial, dapat disimpulkan bahwa:

a. Capital Adequacy Ratio (CAR)

Capital Adequacy Ratio (CAR) tidak berpengaruh signifikan terhadap kinerja keuangan. Hal tersebut dapat dilihat dari nilai signifikansinya 0,153 > dari 0,05 dengan nilai beta negatif, maka $\mathrm{H}_{2.1}$ penelitian ini ditolak. 
b. Biaya Operasional terhadap Pendapatan Operasional (BOPO)

Biaya Operasional terhadap Pendapatan Operasional (BOPO ) berpengaruh terhadap kinerja keuangan. Hal tersebut dapat dilihat dari nilai signifikansinya $0,000<$ dari 0,05 dengan nilai beta negatif, maka $\mathrm{H}_{2.22}$ penelitian ini diterima.

c. Non Performing Loan (NPL).

Return on Asset (ROA) berpengaruh terhadap kinerja keuangan. Hal tersebut dapat dilihat dari nilai signifikansinya $0,650<$ dari 0,05 dengan nilai beta negatif, maka $\mathrm{H}_{2.3}$ penelitian ini ditolak.

\section{Uji $\mathbf{R}^{2}$ atau Koefisien Determinasi}

Koefisien determinasi pada intinya mengukur seberapa jauh kemampuan model dalam menerangkan variasi variabel dependen. Nilai determinasi ditentukan dengan nilai Adjusted R Square.

Berdasarkan hasil output SPSS, tersebut diketahui nilai Adjusted R Square sebesar 0.596 atau 59,6\%. Hal ini menunjukkan bahwa variabel kinerja keuangan dapat dijelaskan oleh variabel manajermen risiko yang diproksikan dengan Capital Adequacy Ratio (CAR), Biaya Operasional terhadap Pendapatan Operasional (BOPO) dan Non performing loan (NPL) sebesar 59,6\% dan sisanya 41,4\% dijelaskan oleh variabel-variabel lain diluar 3 variabel bebas tersebut yang dimasukkan dalam model.

\section{PEMBAHASAN}

\section{Pengaruh manajemen risiko terhadap kinerja keuangan}

Hasil dari penelitian ini menunjukkan bahwa, H1.1 yang menyatakan bahwa secara simultan manajemen risiko yang diproksikan dengan Capital Adequacy Ratio (CAR), Biaya Operasional terhadap Pendapatan Operasional (BOPO) dan Non performing loan (NPL), berpengaruh positif terhadap kinerja keuangan, diterima. Penelitian ini sejalan dengan penelitian Sudiyatno (2013), dan Prastiyaningtyas (2010) yang menyatakan bahwa manajemen risiko yang diproksikan dengan Capital Adequacy Ratio (CAR), Biaya Operasional terhadap Pendapatan Operasional (BOPO) dan Non performing loan (NPL), mempunyai pengaruh positif dan signifikan terhadap ROA secara simultan.

Variabel Capital Adequacy Ratio (CAR), berpengaruh negatif dan tidak signifikan terhadap kinerja keuangan perusahaan perbankan 
syariah yang terdaftar di BEI periode 2011-2016 secara parsial. Jadi H 1.2 yang menyatakan bahwa current ratio (CAR) berpengaruh positif terhadap kinerja keuangn, ditolak. Hasil temuan ini mendukung penelitian mawardi (2005) dan bertentangan dengan hasil penelitian dari Suyono (2005), Naceur dan Kandil (2006). Hasil dari ketiga penelitian tersebut menyatakan bahwa Capital Adequacy Ratio mempunyai pengaruh positif dan signifikan terhadap Return on Asset. Hal ini berarti kemampuan permodalan bank syariah dalam menjaga kemungkinan timbulnya risiko kerugian kegiatan usahanya tidak berpengaruh banyak terhadap tingkat pendapatan atau "earning" yang dihasilkan oleh bank syariah tersebut, yang pada akhirnya tidak berpengaruh terhadap kinerja keuangan bank tersebut. Hal ini, terjadi karena peraturan Bank Indonesia yang mengharuskan menjaga agar Capital Adequacy Ratio (CAR) minimal 8\%, sehingga para pemilik bank menambah modal bank yang berupa fresh money hanya agar Capital Adequacy Ratio (CAR) dapat memenuhi syarat yang ditetapkan Bank Indonesia. Sementara tingkat kepercayaan masyarakat terhadap bank masih rendah karena terjadinya krisis perbankan. Sehingga wajar jika CAR tidak berpengaruh terhadap ROA, karena berapapun modal yang dimiliki bank jika tingkat kepercayaan masyarakat masih rendah maka bank tidak akan bisa menjalankan fungsi intermediasi-nya. Hal ini juga terjadi karena turunnya rata-rata pertumbuhan laba setelah pajak yang disebabkan oleh melemahnya pertumbuhan ekonomi serta pelemahan nilai tukar dolar sedangkan rata-rata pertumbuhan asset perusahaan meningkat (Bareksa.com)

H 1.3 yang menyatakan bahwa Biaya Operasional terhadap Pendapatan Operasional (BOPO) berpengaruh negative terhadap kinerja keuangan, diterima. Penelitian ini sejalan dengan penelitian Kusum dan Suhas (2008), Alkhatib dan Harshch (2012) dan Sudiyatno (2013), yang menyatakan bahwa Biaya Operasional terhadap Pendapatan Operasional (BOPO) berpengaruh terhadap kinerja keuangan. Hal ini berarti tingkat efisiensi bank dalam menjalankan operasinya, berpengaruh terhadap tingkat pendapatan atau "earning" yang dihasilkan oleh bank tersebut. Jika kegiatan operasional dilakukan dengan efisien maka pendapatan yang dihasilkan bank tersebut akan naik. Semakin tinggi rasio BOPO maka dapat dikatakan bahwa kegiatan operasional yang dilakukan bank 
tersebut tidak efisien. Begitu pula sebaliknya semakin rendah rasio BOPO maka kegiatan operasional bank tersebut akan semakin efisien.

Bila semua kegiatan yang dilakukan bank berjalan secara efisien, maka laba yang akan didapat juga semakin besar yang pada akhirnya akan meningkatkan kinerja keuangan bank tersebut.

H1.4 yang menyatakan bahwa non performing loan (NPL) berpengaruh negatif terhadap return saham, ditolak dengan arah yang sama. Hasil temuan ini bertentangan dengan hasil penelitian yang dilakukan oleh Prastiyaningtyas (2010), yang menyatakan bahwa NPL berpengaruh signifikan negatif terhadap ROA bank, Demikian sebaliknya semakin besar non performing loan (NPL) maka semakin besar pula risiko kegagalan kredit yang disalurkan, yang berpotensi menurunkan pendapatan. Dalam hal ini perubahan laba tentunya mempengaruhi besar kecilnya nilai ROA, karena laba merupakan komponen pembentuk return on asset (ROA). Kemudian penelitian yang dilakukan Mawardi, (2005), menyimpulkan bahwa NPL secara signifikan berpengaruh negatif terhadap return on asset (ROA). Sehingga jika semakin besar non performing loan (NPL), akan mengakibatkan menurunnya return on asset, yang juga berarti kinerja keuangan bank yang menurun. Begitu pula sebaliknya, jika non performing loan (NPL) turun, maka return on asset (ROA) akan semakin meningkat, sehingga kinerja keuangan bank dapat dikatakan semakin baik. Non Performing Loan (NPL) tidak tidak mempengaruhi besar kecilnya rasio Return on Asset (ROA). Sehingga dapat disimpulkan bahwa peran bank dalam menjalankan fungsinya sebagai pihak intermediasi tidak berjalan dengan baik.

\section{KESIMPULAN}

Manajemen risiko yang diproksikan dengan CAR, BOPO dan NPL secara bersama sama berpengaruh positif dan signifikan terhadap kinerja keuangan, CAR dan NPL secara parsial tidak signifikan terhadap kinerja keuangan, sedangkan BOPO berpengaruh terhadap kinerja keuangan perusahaan perbankan yang yang terdaftar di BEI tahun 2011 sampai dengan 2016 secara parsial, Hasil manajemen risiko yang tepat dapat meningkatkan kinerja keuangan. 


\section{DAFTAR PUSTAKA}

Al-Qur'an add-Ins

Al-Shubiri, Faris Nasifet al. Financial and Non Financila Determinants of Corporate social responsibility. Asian Economic and Financial Review. Vol. 2(8): 1003.2012.

Arifin. (2005). Peran Akuntan dalam Menegakkan Prinsip Good Corporate Gonvernance pada Perusahaan di Indonesia (Tinjauan Perspektif Teori Keagenan). Pidato sidang senat guru besar Universitas Diponegoro.

Funso, K T., Kolade, A R., \& Ojo, O M. (2012). Credit risk and commercial banks' performance in Nigeria: A Panel model approach. Australian Journal of Business and Management Research. 2(2), 31-38.

Gieseche, K. (2004). Credit risk modelling and valuation: An introduction, Credit Risk. Models and Management. Vol. 2, Cornell University, London.

Hamidah., Purwati, sari, Mardiyanti, Umi. (2013). Pengaruh Corporate Governance dan Leverage Terhadap Profitabilitas Bank Yang Go Publik Di Indonesia Periode 2009-2012. Jurnal Riset Manajemen Sain Indonesia. Vol 4, No 2.

Ihsan, M. (2008). Penilaian kesehatan bank. Percikan: Pemberitaan Ilmiah. 92, 47-55.

Kargi, H.S. (2011). Credit risk and the performance of Nigerian Banks. Zaria: AhmaduBello University.

Ketkar, Kusum W., \& Ketkar, Suhas L. (2008). Performance and profitability of Indian banks in the post liberalization period. World Congress on National Accounts and Economic Performance Measures for Nations. May 13-17-2008, Washington DC.

Mawardi, Wisnu. (2005). Analisis Faktor-Faktor Yang Mempengaruhi Kinerja Keuangan Bank Umum Di Indonesia. Jurnal Bisnis Strategi. Vol 14, No 1, Juli 2005.

Peraturan Bank Indonesia Nomor:10/15/PBI/2008 tentang Kewajiban Penyediaan Modal Minimum Bank Umum. 